AL IBTIDA: JURNAL PENDIDIKAN GURU MI (2019) Vol 6 (1): 90-109

DOI: http://dx.doi.org/ 10.24235/al.ibtida.snj.v6i1.3594

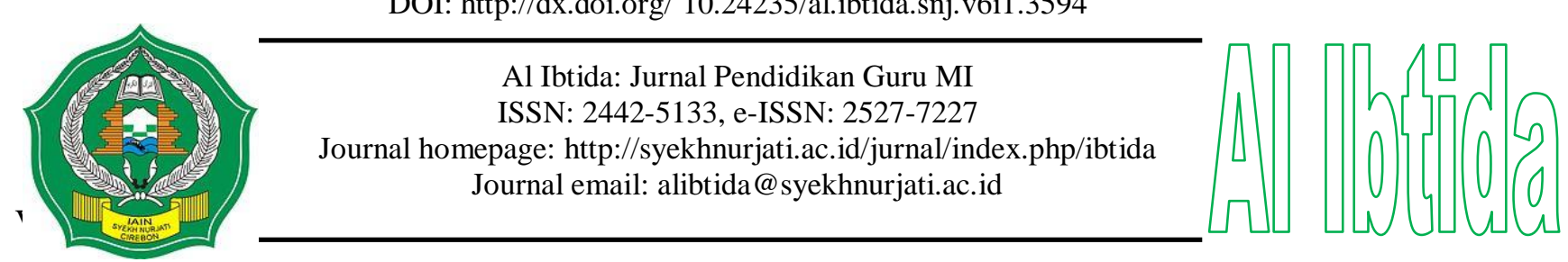

\title{
Developing Concept Approach Based Textbooks of Social Sciences Course for Madrasah Ibtidaiyah Teacher Education
}

\author{
M. Irfan Islamy* \\ *Department of Madrasah Ibtidaiyah Teacher Education, Faculty of Tarbiyah and Teacher Training, \\ Universitas Islam Negeri Maulana Malik Ibrahim Malang \\ Email: irfan.islamy87@uin-malang.ac.id
}

Received: December 12 ${ }^{\text {th }}, 2018$. Accepted: June $17^{\text {th }}, 2019$. Published: June $30^{\text {th }}, 2019$.

\begin{abstract}
The development of the Madrasah Ibtidaiyah/Primary School curriculum has changed several times, from the KBK Curriculum to KTSP Curriculum, then to the 2013 Curriculum. However, the limited textbooks that are in accordance with the curriculum changes are obstacles to learning achievement, especially in Social Sciences course for primary school teacher education. This study aims to develop a social science course textbook for Madrasah Ibtidaiyah/primary school teacher education with a 2013 curriculum-based concept approach that is appropriate for students taking Social Sciences Madrasah Ibtidaiyah/primary school teacher education courses. This research uses a 4-D model with stages of Define, Design, Develop, and restrictions on Desseminate. The results showed that the development of concept approach based social science course textbooks for Madrasah Ibtidaiyah/ primary school got a very decent category with a score of $81 \%$ from material experts, a decent category with a score of $80 \%$ from linguists, and a very decent category with a score of $87 \%$ from design experts. So it can be concluded that the textbooks for Social Sciences of Madrasah Ibtidaiyah/primary school teacher education using the 2013 curriculum-based concept are categorized as feasible.
\end{abstract}

Keywords: concept approach, social studies education, development of textbooks.

\begin{abstract}
Abstrak
Perkembangan kurikulum Madrasah Ibtidaiyah/Sekolah Dasar telah beberapa kali mengalami perubahan, dari Kurikulum Berbasis Kompetensi ke Kurikulum Tingkat Satuan Pendidikan, kemudian ke Kurikulum 2013. Akan tetapi, terbatasnya buku ajar yang sesuai dengan perubahan kurikulum tersebut menjadi kendala terhadap tercapainya pembelajaran, khususnya pada mata kuliah Pendidikan IPS MI/SD. Penelitian ini bertujuan untuk mengembangkan buku ajar mata kuliah Pendidikan IPS MI/SD dengan pendekatan konsep berbasis kurikulum 2013 yang layak untuk mahasiswa yang mengambil mata kuliah Pendidikan IPS MI/SD. Penelitian pengembangan ini menggunakan model 4-D dengan tahapan Define, Design, Develop, dan pembatasan pada Desseminate. Hasil penelitian menunjukkan bahwa pengembangan buku ajar Pendidikan IPS MI/SD mendapatkan kategori sangat layak dengan skor $81 \%$ dari ahli materi, kategori layak dengan skor $80 \%$ dari ahli bahasa, dan kategori sangat layak dengan skor $87 \%$ dari ahli desain. Sehingga dapat
\end{abstract}


disimpulkan bahwa buku ajar mata kuliah Pendidikan IPS MI/SD menggunakan konsep berbasis kurikulum 2013 dikategorikan layak.

Kata Kunci: pendekatan konsep, pendidikan IPS, pengembangan buku ajar.

\section{INTRODUCTION}

In the Basic of Education curriculum in Indonesia, social sciences become an integral part of the national education goals. The Social Sciences shape the national character which is presented in an integrated manner using the term of Social Sciences. Social science is a subject that is theoretically defined as simplifying the discipline of social sciences (Surahman \& Mukminan, 2017; Ross, 2014; Taba, 1967) for educational purposes (Setiawan, 2013). Social science competency is directed at developing students' abilities as individuals who are able to deal with various social problems (Miftahuddin, 2016), from a simple level to a complex level, both social environmental problems that are useful for themselves and society in general (Dewi \& Mukminan, 2016). Social science are presented at the level of Primary School/Madrasah Ibtidaiyah (SD/MI) and Junior High School/Madrasah Tsanawiyah (Middle School/MTs) as the realization of good citizenship (Puspitasari, 2016).

The development of the Basic Education curriculum in Indonesia certainly brought changes to the subject matter. In the Basic Education curriculum education in Indonesia in 1964 and 1965, social science subjects has been taught since class 1 and integrated with Civics Education material. In the 1975 curriculum and the 1994 curriculum, the social science subject was separate from the Civics Education program and then used the term Pendidikan Moral Pancasila (PMP) taught from grades 1 to 6 , while Social Sciences was presented in grades 3 to 6 (Hanafiyah \& Supardi, 2016). Competency Based Curriculum (KBK) and Education Unit Level Curriculum (KTSP), social science subject is taught from class 1 to class 6 with the integration model (Sutrisna \& Wasino, 2010). In the 2013 Curriculum, social science subject is only available in grades 4 to 6 with integrated thematic concepts or integrated with other subjects, and received several reinforcement and material changes based on the demands of the curriculum and the 21 st century, so that there were many developments from social science material presented on the KBK and KTSP curriculum (Miftahuddin, 2016; Muspiroh, 2015; Subadi, Priyono, Dahroni, \& Musyiyam, 2015).

In the Department of Madrasah Ibtidaiyah Teacher Education (PGMI) UIN Maulana Malik Ibrahim Malang, social science subject become compulsory subjects which are divided into 3 levels:

1. Basic Social Sciences Concept ( 2 credits). This course is presented in odd semester (3). The Basic Social Sciences Concept learns about the meaning, purpose and benefits, scope, 
curriculum development, and characteristics of education in Social Sciences, especially at the level of Madrasah Ibtidaiyah/Primary School (MI/SD).

2. Social science education ( 2 credits), presented in even semester (4). This course studies the deepening of social science material for primary school based on the material contained in the applicable curriculum with reinforcement on the concept of core scientific disciplines.

3. Social science Learning (2 credits), presented in odd semester (5). This course is presented with the aim that students are able to teach and develop social science learning at the level of Madrasah Ibtidaiyah/Primary School (MI/SD).

From the development of curriculum and social science courses presented in the PGMI department, it certainly has an impact on various components of learning devices (Wijayati, Degeng, \& Sumarmi, 2016), including teaching materials. Teaching materials are very much needed as scientific references (Prasetiyo \& Perwiraningtyas, 2017) and to study a set of competencies (Nurjannah, 2017), and are needed in the learning process in the classroom (Amin, 2017). One type of teaching material is textbooks. For educators, teaching books are also things that will help and become a reference in developing learning (Suwarni, 2015), which will determine the message and interest in learning (Rohmah, Hariyono, \& Sudarmiatin, 2017). The importance of teaching books can be seen in one indicator of success in achieving competency and learning motivation (Tanjung \& Fahmi, 2015).

Teaching materials in the form of textbooks on the subject of Social Sciences Education in the Primary School based on social science content in the 2013 Curriculum are not yet available, making it difficult for students to find references and learning resources. The absence of textbooks will lead to loss of guidance for students in the learning process (Krismawati, Warto, \& Suryani, 2018). The absence of teaching materials also affects the motivation of students in social studies (Lukman \& Ishartiwi, 2014; Riwanda, Fani, \& Islamy, 2017).

Need analysis on textbook for PGMI FITK students UIN Maulana Malik Ibrahim Malang 2017-2018 academic year which took Social Sciences Education in Madrasah Ibtidaiyah/Primary School, found that as many as $89 \%$ of students stated that they urgently needed social science textbooks, as many as $8 \%$ said they needed, sometimes- sometimes as much as $3 \%$, and no student who answers is not in need and is not very needy.

The rational foundation of students demands on teaching materials is $57 \%$ answering the difficulty in finding references in accordance with the demands of the latest curriculum in 2013, $25 \%$ stating the difficulty in developing social science for Primary School material based on the 2013 curriculum, as many as $14 \%$ said it was difficult to understand the social science for Primary School concepts in the curriculum 2013, and 4\% answered with other reasons. The students reasoned that they were in desperate need of a lack of references on Social Sciences 
subject that had been integrated thematically and discussed the content of social science material in the Primary School/Madrasah Ibtidaiyah based on the 2013 curriculum.

The data shows that the need to develop social science teaching materials into textbooks that are relevant and in accordance with curriculum needs. To support the development of social science textbooks, one approach is needed in the development of material. In terms of material development approaches use a conceptual approach. This approach seeks to define the concepts that exist in the learning material to avoid the meaning of the concept (misconception) (Mosik \& Maulana, 2010; Muna, 2016; Mursalin, 2014; Susilaningsih, Kasmui, \& Harjito, 2016) specifically on the basic concepts of social science found, then sorted from simple concepts to more complex or higher concepts (Jacobsen, Eggen, \& Kauchak, 2002).

\section{METHODS}

This type of research is Research and Development (R \& D). This development research seeks to produce new products, namely social science for Madrasah Ibtidaiyah/Primary School textbooks intended for students majoring in Madrasah Ibtidaiyah Teacher Education (PGMI). The development model used is 4-D (Thiagarajan, 1974). The 4D development model consists of 4 main stages, namely: Define, Design, Develop, and Disseminate.

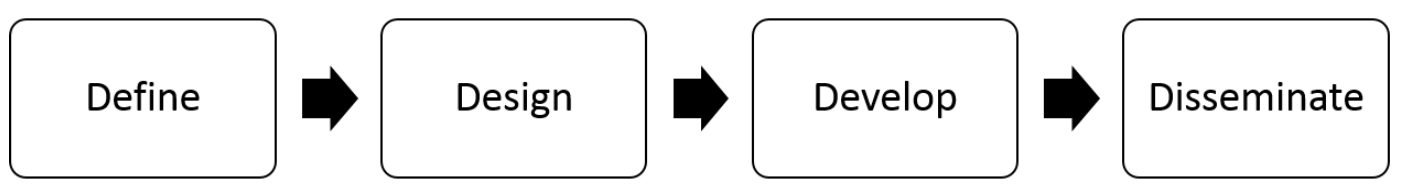

Figure 1. Stage of Development of the 4-D Model

In this development research, the procedure adopted only reached stage 3 , namely Develop, this was based on the research stage of the development divided into 3 stages. The first stage of development is based on the concepts of Social Sciences for MI / Primari School Class 4 in the national curriculum, then grade 5, and finally grade 6. Broadly speaking, the development stage of the 4-D model in developing this Social science teaching book can be seen as follows:

1. Define. At this stage the researcher conducted an analysis of KI (Core Competency) and KD (Basic Competency), as well as the GPA on social science for Primary School material based on the 2013 curriculum. Then, the researchers gathered concepts (concept approaches) related to social science into the categories of social science subject.

2. Design. At this stage the researcher develops the prototype of the Social Sciences course textbook by enriching the concepts that have been analyzed so that they are feasible to become textbooks in accordance with learning resources that can be justified.

3. Develop. At this stage the researcher asks for feasibility validation for material experts, linguists, and media design experts. 
Specifically, the flow of development procedures in this study is illustrated in table 1.

Table 1. 4-D Model Phase in the Development of Social Science for MI/Primary School Education Textbooks

\begin{tabular}{|c|c|c|}
\hline No & Element & Description \\
\hline 1 & Define & $\begin{array}{l}\text { This stage is carried out by Front-end analysis, which is analyzing } \\
\text { students who are students (learner analysis), task analysis (task analysis), } \\
\text { analyzing concepts (concept analysis), and formulating learning } \\
\text { objectives (specifying instructional objectives). }\end{array}$ \\
\hline 2 & & $\begin{array}{l}\text { The design phase aims to design learning devices. The design has four } \\
\text { steps, namely: (1) developing evaluation standards in the form of a } \\
\text { criterion-test construction, (2) selecting media (media selection) that are } \\
\text { used for development, (3) format selection (format selection), which sets } \\
\text { the form teaching material format, (4) designing the first design (initial } \\
\text { design) according to the format of the teaching material that has been } \\
\text { chosen, namely the textbook. }\end{array}$ \\
\hline 3 & Develop & $\begin{array}{l}\text { At this stage, development from the previous stage was carried out with } \\
\text { input from the trial of expert opinion to obtain the feasibility of the results } \\
\text { of the products developed }\end{array}$ \\
\hline
\end{tabular}

After the social science for Primary school education textbook was developed later to get a feasibility score using statistical analysis in processing the data obtained using the Likert scale criterion score analysis. To reinforce the results of the scale of calculation is also done by percentage (\%). The aspects or components to be analyzed consist of: 1) the content/material component (concept, object of study (material and formal), contextual content, actuality of data and facts, update of information, and scope of material); 2) language components (punctuation, vocabulary, sentences, paragraphs, writing rules, and main points); 3) Presentation components (relevance, color composition, size, accuracy of position, and completeness of the message). This analysis is used to process data obtained through the results of the feasibility validity of experts.

Percentage formula for each subject answer with the following formula:

$$
\text { persentase }(\%)=\frac{\sum \text { (number of all questionnaire answers) }}{N \times n \times \text { highest weight }} \times 100 \%
$$

\section{Information:}

$\mathrm{N}=$ number of respondents

$\mathrm{n}=$ number of all questionnaire items 
To be able to give meaning and decision making, the provisions used are as it follows.

Table 2. Criteria for Feasibility Percentage of Education Textbooks for MI / SD

\begin{tabular}{ccc}
\hline Level of Achievement $(\%)$ & Qualification & Notes \\
\hline $86-100$ & Very decent & No Revision Needed \\
$71-85$ & Worth it & No Revision Needed \\
$56-70$ & Enough & worth Revision \\
$41-55$ & Less & worth Revision \\
$0-40$ & Very Unworthy & Revision \\
\hline
\end{tabular}

\section{RESULTS AND DISCUSSION}

\section{The Define Stage of Developing Textbooks for Social Sciences Education Course}

1. Front end analysis. There are three basic problems in the social science for primary school course, namely the development of social science for primary school curriculum from KTSP to $\mathrm{K}-13$, which then has an impact on the development of social science for primary school content and material, and the difficulty of references as learning resources, as well as need assessment the need for teaching materials from students. Of the three basic problems, it becomes the basis for thinking to do a product development in order to overcome and innovate in learning social science for primary school courses.

2. Student analysis (learner analysis). The students referred to in this development are students who have passed the social science for primary school Basic Concepts course and proceed to the Social Sciences for Primary School subject.

3. Analysis of tasks (task analysis). The task analysis in question is the main skills then developed into tasks assigned to students. In this step, skills are defined as learning outcomes and sub-learning outcomes.

4. Analysis of concepts (concept analysis). Development of material in social science for primary school textbooks uses a conceptual approach. At this stage, there are several concrete steps taken, namely:

a. Using the 2016/2017 revised curriculum in accordance with Permendikbud No. 21 of 2016.

b. The textbook used to obtain the concept is the official textbook from the Ministry of Education and Culture of the Republic of Indonesia.

c. Identifying Core Compentency of Knowledge (KI 3) and Basic Competencies (KD) of social science for primary school from grade 4, Grade 5, and grade 6.

d. From the identification of KI 3 and KD social science for primary school then the main concepts can be determined based on the material presented in the 2013 social science for 
primary school curriculum.

To get the concepts of the social sciences that are used as the basis for developing the material in the Social Sciences/Primary School Education course, it is necessary to look at the KI and KD social science for primary school Curriculum 2013. The 2013 curriculum has undergone 2 revisions to KI and KD, which first in 2014 with the basis of Permendikbud No. 57 of 2014 and the second in 2016 with the basis of Permendikbud No. 21 of 2016.

Concept mapping is taken in the 2013 curriculum based on the revision of Permendikbud No. 21 of 2016. The concept of the social sciences will be categorized in scientific disciplines, so that the core concept will be obtained, and will be categorized as a sub-discussion material. The concepts of the Social Sciences found in KI and KD (Cognitive/Knowledge) IPS MI/SD Curriculum 2013 the 2016 revision can be seen in table 3 for class 4 , table 4 for class 5 , table 5 for class 6.

Table 3. Core Competence and Basic Competence Knowledge of Social Sciences for Grade 4th

\section{Core Competence Basic Competence}

\begin{tabular}{|c|c|c|c|}
\hline \multirow{4}{*}{$\begin{array}{l}\text { Understanding } \\
\text { factual knowledge } \\
\text { by observing and } \\
\text { asking questions } \\
\text { based on curiosity } \\
\text { about him, God's } \\
\text { creatures and } \\
\text { activities, and } \\
\text { objects that are } \\
\text { found at home, at } \\
\text { school and at the } \\
\text { playground }\end{array}$} & 3.1 & $\begin{array}{l}\text { Identify the characteristics of space and } \\
\text { the use of natural resources for the } \\
\text { welfare of the community from the city } \\
\text { / regency level to the provincial level }\end{array}$ & $\begin{array}{l}\text { 1. Space } \\
\text { 2. Natural resources }\end{array}$ \\
\hline & 3.2 & $\begin{array}{l}\text { Identifying social, economic, cultural, } \\
\text { ethnic and religious diversity in the } \\
\text { local province as an Indonesian identity }\end{array}$ & $\begin{array}{l}\text { Social, economic, } \\
\text { cultural, ethnic and } \\
\text { religious diversity }\end{array}$ \\
\hline & 3.3 & $\begin{array}{l}\text { Identify economic activities in } \\
\text { improving people's lives in the fields of } \\
\text { work, social and culture in the } \\
\text { surrounding environment to the } \\
\text { province }\end{array}$ & $\begin{array}{l}\text { 1. Economic activity } \\
\text { 2. Work }\end{array}$ \\
\hline & 3.4 & $\begin{array}{l}\text { Identifying Hindu, Buddhist and } \\
\text { Islamic kingdoms and their influence } \\
\text { on the lives of today's people in the } \\
\text { local environment }\end{array}$ & $\begin{array}{l}\text { 1. Hinduism } \\
\text { 2. The Buddhist } \\
\text { Kingdom } \\
\text { 3. Islamic Kingdom }\end{array}$ \\
\hline
\end{tabular}

Table 4. Core Competence and Basic Competence Knowledge of Social Sciences for Grade 5th

\begin{tabular}{|c|c|c|c|}
\hline Core Competence & \multicolumn{2}{|c|}{ Basic Competence } & Core Concepts \\
\hline $\begin{array}{l}\text { Understanding factual } \\
\text { and conceptual } \\
\text { knowledge by } \\
\text { observing, asking } \\
\text { questions and trying }\end{array}$ & 3.1 & $\begin{array}{l}\text { Identify the geographical characteristics } \\
\text { of Indonesia as an archipelagic / } \\
\text { maritime and agrarian country and its } \\
\text { influence on economic, social, cultural, } \\
\text { communication and transportation life }\end{array}$ & $\begin{array}{l}\text { 1. Geographical } \\
\text { characteristics } \\
\text { 2. Island / maritime } \\
\text { and agrarian } \\
\text { countries }\end{array}$ \\
\hline $\begin{array}{l}\text { based on curiosity } \\
\text { about him, God's } \\
\text { creatures and } \\
\text { activities, and objects } \\
\text { found at home, at }\end{array}$ & 3.2 & $\begin{array}{l}\text { Analyze the forms of human interaction } \\
\text { with the environment and their effects } \\
\text { on the social, cultural and economic } \\
\text { development of the Indonesian people }\end{array}$ & $\begin{array}{l}\text { 1. Human and } \\
\text { environmental } \\
\text { interactions } \\
\text { 2. Social, cultural } \\
\text { and economic }\end{array}$ \\
\hline
\end{tabular}


school and on the

development

playground.

\begin{tabular}{ll}
\hline $\begin{array}{l}\text { Analyzing the role of the economy in an } \\
\text { effort to improve people's lives in the } \\
\text { social and cultural fields to strengthen } \\
\text { national unity and unity }\end{array}$ & $\begin{array}{l}\text { 1. Role and } \\
\text { function of the } \\
\text { economy }\end{array}$ \\
$\begin{array}{ll}\text { 2. National unity } \\
\text { and unity }\end{array}$ \\
\hline $\begin{array}{l}\text { Identify important factors causing the } \\
\text { occupation of the Indonesian nation and } \\
\text { the efforts of the Indonesian people in } \\
\text { maintaining their sovereignty }\end{array}$ & $\begin{array}{l}\text { 1. Colonialism } \\
\text { 2. Maintaining } \\
\text { independence }\end{array}$ \\
\hline
\end{tabular}

Table 5. Core Competence and Basic Competence Knowledge of Social Sciences for Grade 6th

\begin{tabular}{|c|c|c|c|}
\hline Core Competence & \multicolumn{2}{|c|}{ Basic Competence } & Core Concepts \\
\hline \multirow{4}{*}{$\begin{array}{l}\text { Understanding } \\
\text { factual and } \\
\text { conceptual } \\
\text { knowledge by } \\
\text { observing, asking } \\
\text { questions and trying } \\
\text { based on curiosity } \\
\text { about him, God's } \\
\text { creatures and } \\
\text { activities, and } \\
\text { objects found at } \\
\text { home, at school and } \\
\text { on the playground }\end{array}$} & 3.1 & $\begin{array}{l}\text { Mengidentifikasi karakteristik geografis } \\
\text { dan kehidupan sosial budaya, ekonomi, } \\
\text { politik di wilayah ASEAN }\end{array}$ & $\begin{array}{l}\text { 1. Geographical } \\
\text { characteristics } \\
\text { 2. ASEAN }\end{array}$ \\
\hline & 3.2 & $\begin{array}{l}\text { Analyzing socio-cultural changes in the } \\
\text { context of modernizing the Indonesian } \\
\text { nation }\end{array}$ & $\begin{array}{l}\text { 1. Social Change } \\
\text { 2. Modernization }\end{array}$ \\
\hline & 3.3 & $\begin{array}{l}\text { Analyzing Indonesia's position and role } \\
\text { in cooperation in the fields of economy, } \\
\text { politics, social, culture, technology and } \\
\text { education within the scope of ASEAN }\end{array}$ & $\begin{array}{l}\text { Cooperation and role } \\
\text { of the State }\end{array}$ \\
\hline & 3.4 & $\begin{array}{l}\text { Understanding the meaning of the } \\
\text { proclamation of independence, efforts to } \\
\text { maintain independence, and efforts to } \\
\text { develop a prosperous national life }\end{array}$ & $\begin{array}{l}\text { The proclamation of } \\
\text { independence }\end{array}$ \\
\hline
\end{tabular}

The concept will be categorized based on the disciplines of the Social Sciences to obtain material emphasis based on the characteristics of its scientific discipline. The categorization results can be seen in table 6 .

Table 6. Categories of Social Sciences based on Initial Concept Mapping

\begin{tabular}{lll}
\hline Class & Concept Mapping & Social Sciences Discipline \\
\hline \multirow{4}{*}{ Room } & 1. Geography \\
& Natural resources & 2. Sociology \\
& & 3. Anthropology \\
& & 4. Economy \\
\cline { 2 - 3 } 4 & Social, economic, cultural, ethnic and religious diversity & 1. Geography \\
& & 2. Economy \\
& & 3. Sociology \\
& Economic activity & 4. Anthropology \\
\cline { 2 - 3 } & Work & 1. Economy \\
& 2. Sociology \\
\cline { 2 - 3 } & Hindu kingdom & 3. Anthropology \\
\hline
\end{tabular}




\begin{tabular}{|c|c|c|}
\hline Class & Concept Mapping & Social Sciences Discipline \\
\hline & Buddhist kingdom & 2. Sociology \\
\hline & Islamic kingdom & 3. Anthropology \\
\hline & & 4. Economy \\
\hline \multirow{13}{*}{5} & Geographical Character & 1. Geography \\
\hline & Islands / maritime and agrarian countries & 2. Economy \\
\hline & Human and environmental interactions & 1. Sociology \\
\hline & Social, cultural and economic development & 2. Anthropology \\
\hline & & 3. Economy \\
\hline & & 4. Geography \\
\hline & Economic role and function & 1. Economy \\
\hline & Unity and unity of the nation & 2. Politic \\
\hline & Colonialism & 1. History \\
\hline & Maintain independence & 2. Politic \\
\hline & & 3. Geography \\
\hline & & 4. Sociology \\
\hline & & 5. Anthropology \\
\hline \multirow{12}{*}{6} & Geographical Characteristics & 1. Geography \\
\hline & ASEAN & 2. Economy \\
\hline & & 3. Politic \\
\hline & & 4. History \\
\hline & & 5. Sociology \\
\hline & & 6. Anthropology \\
\hline & Social change & 1. Sociology \\
\hline & Modernization & 2. Anthropology \\
\hline & Cooperation of ASEAN countries & 1. Economy \\
\hline & & 2. Politic \\
\hline & The proclamation of independence & 1. History \\
\hline & & 2. Politic \\
\hline
\end{tabular}

Departing from the categorization, the material substance so that integration in social studies can be achieved, the main social science disciplines will be integrated with the social sciences with an integrated approach. After the concept development stage is done, then proceed to the last step in the define stage, namely the Formulation of Learning Objectives (Specifying Intensive Objectives). The intended learning objective is the achievement and sub-achievement of learning which the final part is after the task and concept analysis is carried out.

\section{The Design Stage of Developing Textbooks for Social Sciences Education Course}

Based on the stages on define, the next step is the design stage. At the design stage there are 4 steps defined, namely:

1. The form of the test chosen after each learning achievement is a written test with multiple choice format;

2. The media used to support the concepts developed are either static or moving graphs (video);

3. Format of writing is teaching material in the form of textbooks; 
4. The initial design is a textbook design that will be developed based on the categories:

a. Foreword

b. Table of contents

c. Instructions for Textbooks

d. Subject matter

1) Learning Outcomes

2) Sub-material achievements

3) Material description

4) Summary

5) Tests

6) Glossary

7) Reference List

This stage can be a design stage based on development at the define stage which can be seen in table 7.

Table 7. Systematic design of social science for madrasah ibtidaiyah/primary school textbooks based on a conceptual approach

\begin{tabular}{|c|c|c|}
\hline Class & Concept Mapping & Development Results \\
\hline \multirow{18}{*}{4} & Room & 1. Basic Map Concept \\
\hline & Natural resources & 2. The concept of space \\
\hline & & 3. Natural Resources \\
\hline & Social, economic, cultural, ethnic & 1. Socio-cultural diversity \\
\hline & and religious diversity & 2. Economic diversity \\
\hline & & 3. Ethnic diversity \\
\hline & & 4. Diversity of Religion \\
\hline & Economic activity & 1. Economic Activity \\
\hline & Work & 2. Availability of economic resources \\
\hline & & 3. Various Jobs \\
\hline & & 4. Economic and Employment Activities \\
\hline & & 5. Economic Institution \\
\hline & & 6. Business to improve prosperity \\
\hline & Hindu kingdom & 1. The basic concept of history \\
\hline & Buddhist kingdom & 2. Indonesian Hindu Kingdom \\
\hline & Islamic kinodom & 3. Indonesian Buddhist Kingdom \\
\hline & & 4. Indonesian Islamic Kingdom \\
\hline & & $\begin{array}{l}\text { 5. Effects of Hindu, Buddhist and Islamic } \\
\text { kingdoms in Indonesia }\end{array}$ \\
\hline \multirow{5}{*}{5} & Geographical Character & 1. Location and Area of Indonesia in Map \\
\hline & Islands/maritime and agrarian & $\begin{array}{l}\text { 2. Natural Conditions in the Territory of } \\
\text { Indonesia }\end{array}$ \\
\hline & & 3. Population characteristics \\
\hline & & $\begin{array}{l}\text { 4. Islands/maritime and agricultural countries as } \\
\text { well }\end{array}$ \\
\hline & & $\begin{array}{l}\text { 5. The influence of maritime and agrarian } \\
\text { countries on economic social life and }\end{array}$ \\
\hline
\end{tabular}




\begin{tabular}{|c|c|c|}
\hline \multirow[t]{17}{*}{ Class } & \multirow[t]{2}{*}{ Concept Mapping } & Development Results \\
\hline & & \\
\hline & \multirow{6}{*}{$\begin{array}{l}\text { Human and environmental } \\
\text { interactions } \\
\text { Social, cultural and economic } \\
\text { development }\end{array}$} & 1. Social interaction \\
\hline & & 2. Social cultural interactions \\
\hline & & 3. Human interaction with the environment \\
\hline & & 4. Dissemination / aculturation \\
\hline & & 5. Socio-cultural development \\
\hline & & 6. Cultural and economic social development \\
\hline & Economic role \& function & 1. Basic Concepts of Economics \\
\hline & \multirow{2}{*}{ Unity \& unity of the nation } & 2. Economic activities of the Indonesian people \\
\hline & & 3. Economic activities in mining and industry \\
\hline & \multirow{6}{*}{$\begin{array}{l}\text { Colonialism } \\
\text { Protecting Country }\end{array}$} & 1. The basic concept of imperialism and \\
\hline & & colonialism \\
\hline & & 2. European occupation in Indonesia \\
\hline & & 3. Resistance of the Indonesian people \\
\hline & & 4. National movement organization \\
\hline & & 5. Japanese military occupation in Indonesia \\
\hline \multirow{14}{*}{6} & \multirow{6}{*}{$\begin{array}{l}\text { Geographical Characteristics } \\
\text { ASEAN }\end{array}$} & 1. The basic concept of imperialism and \\
\hline & & colonialism \\
\hline & & 2. European occupation in Indonesia \\
\hline & & 3. Resistance of the Indonesian people \\
\hline & & 4. National movement organization \\
\hline & & 5. Japanese military occupation in Indonesia \\
\hline & Social change & 1. Changes in Socio-Culture in Indonesia \\
\hline & Modernization & $\begin{array}{l}\text { 2. Modernization in the fields of science and } \\
\text { technology, economics, education and } \\
\text { democracy }\end{array}$ \\
\hline & \multirow{3}{*}{$\begin{array}{l}\text { Cooperation of ASEAN } \\
\text { countries }\end{array}$} & 1. Export and Import \\
\hline & & 2. Delivery of Labor Exchange \\
\hline & & 3. ASEAN Economic Community \\
\hline & \multirow{3}{*}{$\begin{array}{l}\text { The proclamation of } \\
\text { independence }\end{array}$} & 1. Proclamation of Independence \\
\hline & & 2. Building a sovereign nation's life \\
\hline & & $\begin{array}{l}\text { 3. The role of the Indonesian people in building } \\
\text { the international community }\end{array}$ \\
\hline
\end{tabular}

\section{Presentation of Trial Data}

Data presented, namely data obtained from the following stages:

1. Data validation of material experts;

2. Linguist validation data;

3. Validation of media / learning design experts;

In the validation stage, each expert is given an assessment instrument and the results of the print out of textbook products are given a score according to the expertise of each validator. The highest score of the instrument is five (5), while the lowest score is one (1). The importance of the validation and trial process is to determine the perceptions of experts and users about the developed textbook products. Furthermore the results of the perception or response are processed using a Likert scale. 
Likert scale is used to determine the attitudes, opinions, and perceptions of experts in the field of study on the material presented, book design experts/teaching materials on product design, as well as linguists on the language used in textbooks, understanding, convenience, and student and teacher interest in textbook material presentation. To obtain responses and perceptions from each validator, an instrument was used in the form of a response questionnaire with a number of different questions. A total of 26 questions for material experts, 20 questions for linguists, 23 questions for expert learning design, 35 questions for design/learning media experts, 17 questions for students. The following are the results of the data of each respondent.

\section{Trial to Learning Materials Experts}

The questionnaire component is in the form of; material coverage, material accuracy, updating, stimulating curiosity, developing life skills, and containing contextual insights. Table 8 presents a recap of the results of data presentation by content/material experts.

Table 8. Questionnaire Score Data based on Material Experts

\begin{tabular}{|c|c|c|}
\hline No & Statement Item & Score \\
\hline 1 & Extent of Material & 4 \\
\hline 2 & Depth of Material & 4 \\
\hline 3 & Accuracy of facts & 4 \\
\hline 4 & Accuracy of theory and concept & 4 \\
\hline 5 & Principle accuracy/law & 4 \\
\hline 6 & Procedure Accuracy & 4 \\
\hline 7 & Accordance with scientific development & 5 \\
\hline 8 & Update examples and references & 5 \\
\hline 9 & Growing work ethic & 4 \\
\hline 10 & Growing innovative spirit & 4 \\
\hline 11 & Grow creativity & 4 \\
\hline 12 & Grow competitiveness & 4 \\
\hline 13 & Growing curiosity & 4 \\
\hline 14 & Give a challenge to learn more & 3 \\
\hline 15 & Develop personal skills & 3 \\
\hline 16 & Develop social exhaustion & 5 \\
\hline 17 & Develop academic skills & 4 \\
\hline 18 & Appreciation of cultural diversity & 4 \\
\hline 19 & Appreciation of community pluralism & 4 \\
\hline 20 & Growing nationalism & 4 \\
\hline 21 & Presenting examples or illustrations & 4 \\
\hline & Total Amount & 85 \\
\hline
\end{tabular}

Source: data processed

The data in table 8 are based on a quantitative assessment of questionnaires from material experts, the textbook products have met the eligibility criteria even though they have to go through improvements according to the advice and responses of material experts. The number of question items for material experts about the text book responses amounted to 21 question items. Thus the highest score for material experts is 105 and the lowest number of scores is 21 . Based 
on the score of the answer item questions from a material expert in the social science for Primary school teaching book, it can be analyzed as follows.

The number of question items answered with the SL category $=3 \times 5 \quad=15$

The number of questions answered by the category $L \quad=16 \times 4 \quad=64$

The number of questions answered by the CL category $\quad=2 \times 3=6$

The number of question items answered with the TL category $=0 \times 2=0$

The number of question items answered with the STL category $=0 \times 1 \quad=0+$

Total Amount $=85$

The total score of the answers obtained from the results of the trial of material experts, namely 85. Based on these data, the level of material expert approval of the social science for Primary school textbook $=86.15 \%(85: 105 \times 100 \%)$ than expected $100 \%$. The criteria can be described as follows.

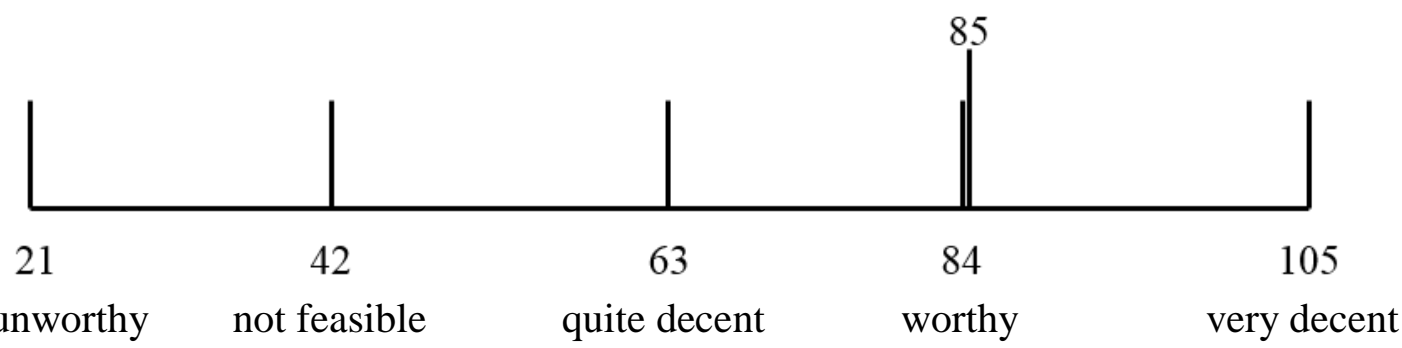

It was concluded that the social science for Primary school textbook on products that were developed in broad outline had met decent standards and were in decent qualifications and did not need to be revised.

\section{Trial to Language Expert}

The questionnaire component is in the form of; language suitability with student development, use of communicative language, dialogue and interactive language, language fluency, thought grooves, coherence, conformity with correct Indonesian, use of terms and symbols / symbols. In table 9, a recapitulation of the data presented by linguists is presented.

Table 9. Questionnaire Score Data Response of Language Experts

\begin{tabular}{clc}
\hline No & \multicolumn{1}{c}{ Statement Item } & Score \\
\hline 1 & Language accuracy with the level of thinking of users (students) & 4 \\
2 & Accuracy with the level of social and emotional users (students) & 4 \\
3 & Message conformity & 4 \\
4 & Suitability of the illustration with the substance of the message & 5 \\
5 & The accuracy of the user's motivation in responding to messages & 4 \\
6 & There is a level of critical thinking for users & 4 \\
7 & Conformity of sentence structure & 4 \\
8 & Use standard terms & 4 \\
9 & Linkages between chapters & 4 \\
10 & Linkages between chapters with sub-chapters & 3 \\
11 & Linkages between the sub chapters in the chapter & 3 \\
\hline
\end{tabular}




\begin{tabular}{clc}
\hline No & \multicolumn{1}{c}{ Statement Item } & Score \\
\hline 12 & Linkages between paragraphs in the chapter & 3 \\
13 & Linkages between sentences in one paragraph & 4 \\
14 & Integrity of meaning in the chapter & 4 \\
15 & Integrity of meaning in the sub-chapter & 4 \\
16 & Integrity of meaning in paragraph & 4 \\
17 & Accuracy of grammar & 4 \\
18 & Spelling accuracy & 4 \\
19 & Consistency in the terms used & 5 \\
20 & Consistency in the image used & 4 \\
\hline \multicolumn{2}{c}{ Total Amount } \\
\hline
\end{tabular}

Source: data processed

The recapitulation of the data in the table 9 above is the result of an assessment of the questionnaire responses from linguists by $80 \%$. The number of questions for linguists about the text book responses amounts to 20 questions. Thus the highest score for linguists is 100 and the lowest number of scores is 20 . Based on the score of the answer items the questions from a linguist can be analyzed as it follows.

The number of question items answered with the SL category $\quad=2 \times 5 \quad=10$

The number of questions answered by the category $L \quad=16 \times 4=64$

The number of questions answered by the CL category $\quad=2 \times 3=6$

The number of question items answered with the TL category $=0 \times 2=0$

The number of question items answered with the STL category $=0 \times 1 \quad=0+$

$\begin{array}{ll}\text { Total Amount } & =80\end{array}$

The number of answer scores obtained from the results of the linguist's trial, namely 80 . Based on these data, the level of linguist approval of the social science for Primary school textbook $=80 \%(80: 100 \times 100 \%)$ than expected $100 \%$. The criteria can be described as follows.

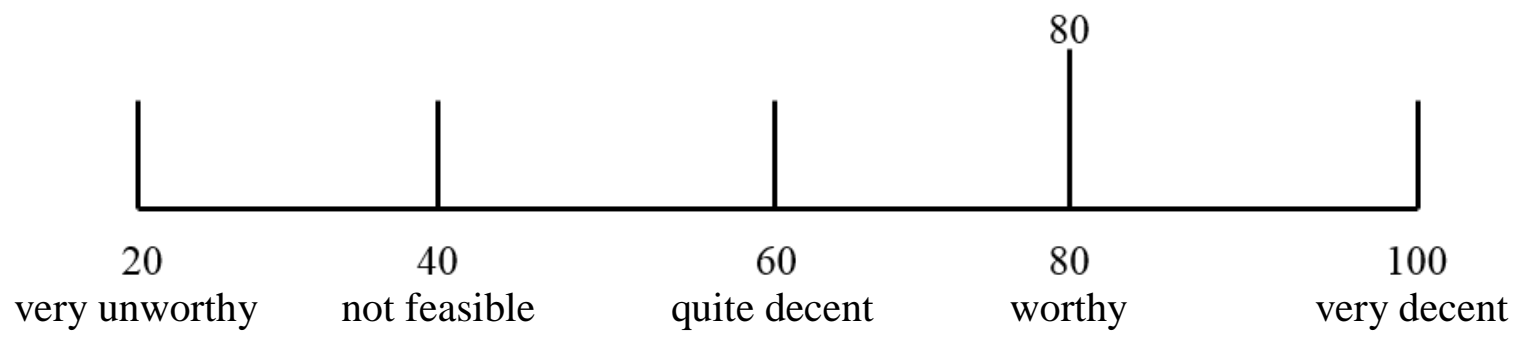

Data obtained from linguists then averages 80 between decent categories. It was concluded that the language of the product that was developed in broad outline had met decent standards and was in decent qualifications and did not need to be revised.

\section{Trial to Learning Design Expert}

The questionnaire component is in the form of teaching material size, cover design, cover illustration, design of book content, cover typography and content of teaching materials, typography of teaching material contents, illustrations and drawings of teaching materials, and 
color usage. Table 10 presents a recap of the results of data presentation by design / learning media experts.

Table 10. Score Data Questionnaire for Designers' Responses

\begin{tabular}{|c|c|c|}
\hline No & $\begin{array}{l}\text { Statement Item } \\
\end{array}$ & Score \\
\hline 1 & Using the ISO A4 textbook standard (210 x $297 \mathrm{~mm})$ & 5 \\
\hline 2 & The accuracy of the page with the material presented & 5 \\
\hline 3 & Unity of layout & 5 \\
\hline 4 & Harmony in the use of color elements, illustrations, and cover typography & 4 \\
\hline 5 & Clarity of the meaning of the cover & 4 \\
\hline 6 & $\begin{array}{l}\text { Suitability of color contrast with background text, illustrations, and decorative } \\
\text { cover elements }\end{array}$ & 4 \\
\hline 7 & $\begin{array}{l}\text { The design of the illustration / cover image depicts social science for Primary } \\
\text { school }\end{array}$ & 4 \\
\hline 8 & $\begin{array}{l}\text { The cover design is in accordance with the character of the object of study in } \\
\text { IPS / Elementary School Education }\end{array}$ & 4 \\
\hline 9 & $\begin{array}{l}\text { The shape, color, and size match reality so that it does not cause } \\
\text { misinterpretation }\end{array}$ & 4 \\
\hline 10 & The content layout is consistent with the pattern & 5 \\
\hline 11 & Accuracy in placing elements of layout (title, subtitle, illustration) & 4 \\
\hline 12 & Clarity of use of vertical and horizontal spaces & 4 \\
\hline 13 & Clarity in the separation of texts at the beginning and end of paragraphs & 5 \\
\hline 14 & Accuracy in the placement of chapter titles & 5 \\
\hline 15 & Proportional proportionality, and margins already & 5 \\
\hline 16 & The accuracy of the design of writing the chapter title & 4 \\
\hline 17 & $\begin{array}{l}\text { Display subtitles using shading and border shaped boxes accompanied by } \\
\text { shadows are sufficient for a subtitles }\end{array}$ & 4 \\
\hline 18 & The order of titles and subtitles in the order & 5 \\
\hline 19 & $\begin{array}{l}\text { Suitability of illustrations both in the form of images, photos, and caricatures } \\
\text { displayed in teaching books with contents }\end{array}$ & 5 \\
\hline 20 & Clarity of the interaction description in the picture & 4 \\
\hline 21 & $\begin{array}{l}\text { The placement of titles, subtitles, illustrations and captions helps } \\
\text { understanding }\end{array}$ & 4 \\
\hline 22 & Clarity of letters used on covers and contents so that it is easy to read & 5 \\
\hline 23 & $\begin{array}{l}\text { The size of the book title that is more dominant compared to the author's name } \\
\text { is proportional }\end{array}$ & 5 \\
\hline 24 & Accuracy of letter and font combinations & 5 \\
\hline 25 & $\begin{array}{l}\text { It is appropriate not to use decorative letters because it can reduce the } \\
\text { readability and clarity of the information conveyed }\end{array}$ & 4 \\
\hline 26 & $\begin{array}{l}\text { The consistency of textbooks with the appearance of the fonts on the textbook } \\
\text { text and contents }\end{array}$ & 5 \\
\hline 27 & $\begin{array}{l}\text { The accuracy of typography of teaching materials does not use too many types } \\
\text { of letters }\end{array}$ & 5 \\
\hline 28 & The accuracy of the use of bold, italic and capital & 5 \\
\hline 29 & The accuracy of font size & 5 \\
\hline 30 & $\begin{array}{l}\text { The title hierarchy has been systematic so that it makes understanding easier } \\
\text { to order }\end{array}$ & 4 \\
\hline 31 & Images in textbooks can generate attraction with accurate, realistic views & 4 \\
\hline 32 & $\begin{array}{l}\text { Textbook design meets creative, dynamic criteria, and can add depth to } \\
\text { understanding }\end{array}$ & 4 \\
\hline 33 & Color selection according to the age of the user & 4 \\
\hline 34 & The accuracy of using colors with the background & 4 \\
\hline
\end{tabular}




\begin{tabular}{ccc}
\hline No & Statement Item & Score \\
\hline 35 & $\begin{array}{l}\text { The accuracy of the use of colors in textbooks to distinguish between } \\
\text { components }\end{array}$ & 4 \\
\hline & Total Amount & $\mathbf{1 5 6}$ \\
\hline
\end{tabular}

Source: questionnaire data after processing

The recapitulation of data in table 10 is the result of a questionnaire assessment of responses from design experts getting a score of $89 \%$. The number of question items for design experts about textbook responses is 35 questions. Thus the highest score for design experts is 175 and the lowest number of scores is 35 . Based on the score of the answer items the questions from a design expert can be analyzed as follows.

The number of question items answered with the SL category $=16 \times 5=80$

The number of questions answered by the category $L \quad=19 \times 4=76$

The number of question items answered with the CL category $=0 \times 3=0$

The number of question items answered with the TL category $=0 \times 2=0$

The number of question items answered with the STL category $=0 \times 1 \quad=0+$

$\begin{array}{ll}\text { Total Amount } & =128\end{array}$

The total score of the answers obtained from the results of the design expert trial, which is 128. Based on these data, the level of expert design approval for the social science for Primary school textbook $=87.64 \%(156: 175 \times 100 \%)$ than expected $100 \%$.

The criteria can be described as follows.

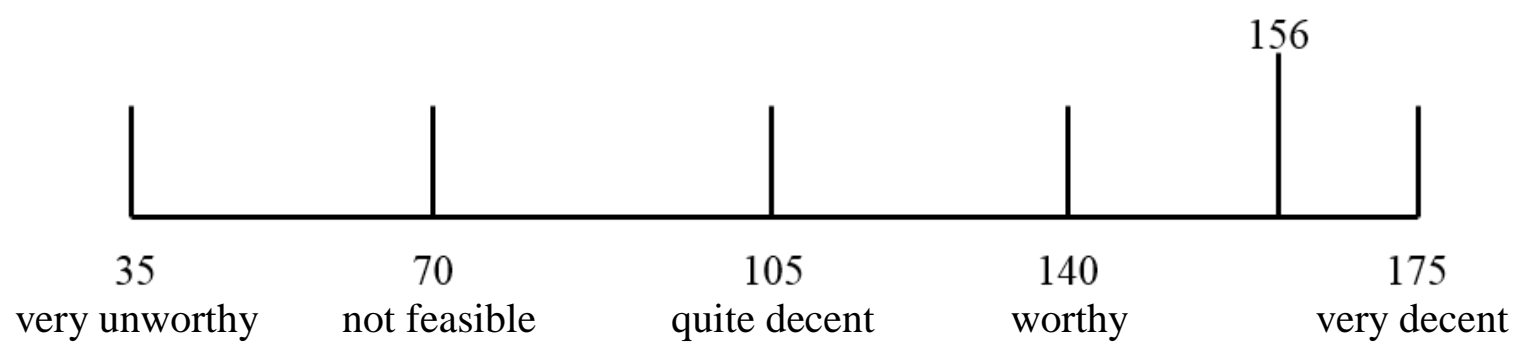

Data obtained from design experts, the average 156 is located between the feasible and very feasible categories. It was concluded that the learning design on products that were developed in broad outline had met decent standards and did not need to be revised.

Development of textbooks social science for Primary school courses with the 2013 curriculum-based concept approach in its preparation pay attention to the rules and opinions of how many experts, from material experts, language, and learning design. The results of the feasibility of products from all experts into a table, it of can be noted in table 11 below. 
Table 11. Recapitulation of Results of Evaluation of Expert Validation

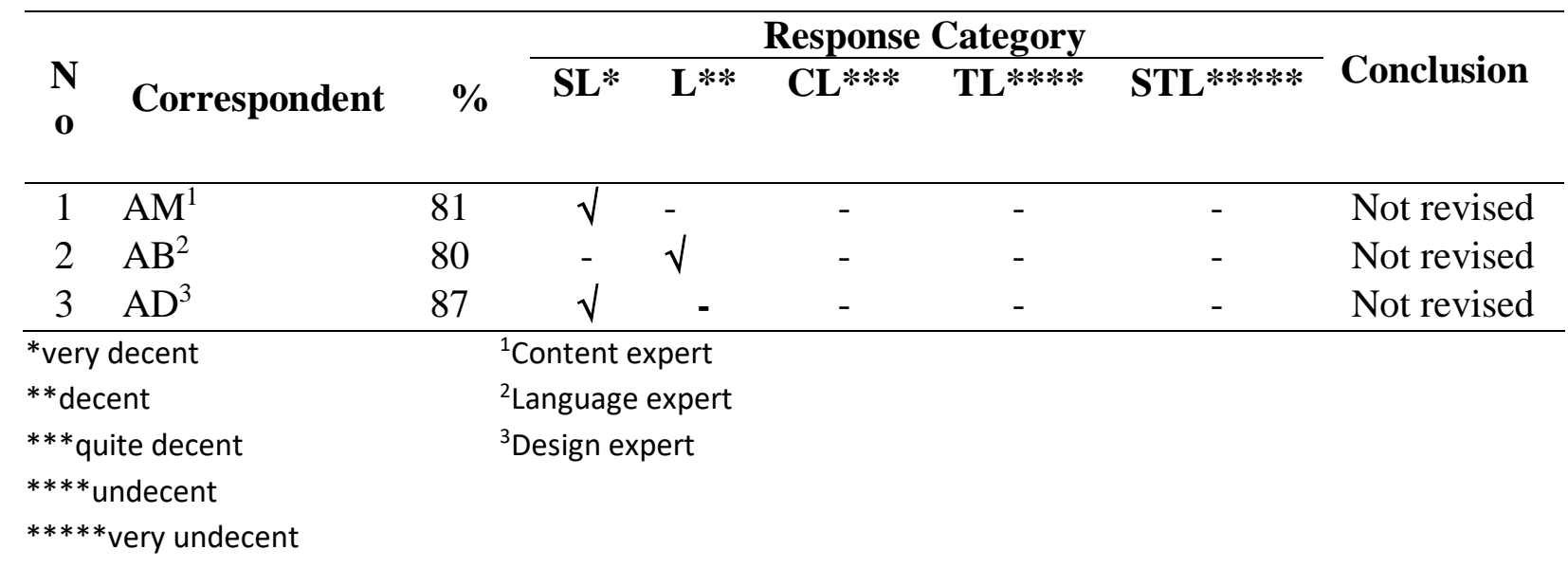

The results of all recapitulation can be concluded that the teaching materials of the social science for Primary school subject with the 2013 Curriculum-based concept approach have met appropriate standards. Book design presentation refers to expert input to make it look interesting so that it creates feelings and reactions in motivation to read (Retariandalas, 2017). The presentation of the contents of the book material is adjusted to the learning objectives and each learning material begins with a concept map. Concept maps can have a positive influence on the learning process and help strengthen readers' memories and memories (Susanti, 2016). Each end of the learning material is given a glossary that is devoted to providing important terms from the concepts of the social sciences contained in the material.

Each content material that requires presentation support in the form of graphics and video, will be equipped with pictures and videos. Especially for supporting videos of learning materials directed towards using hyperlinks to the youtube site. The graphics and videos supporting the learning material were chosen appropriately to be adapted in order to provide understanding and memory of the information presented in the text.

Product textbooks of social science for Primary school are equipped with the following things, namely:

1. Guidelines for the use of books that aim to help readers to use textbook products properly;

2. A table of contents that aims to help readers understand the systematics of textbook products as a whole;

3. Concept maps that aim to help readers understand the systematic learning material of teaching book products;

4. Glossary of glossary of social science concepts that aim to help readers understand important terms related to the concepts of social sciences contained in learning material;

5. A summary that aims to help readers relate to learning material on read textbook products; 
6. Problem training that aims to measure the cognitive competence of the reader towards learning material in teaching book products;

7. Bibliography which aims as scientific responsibility and reference for readers regarding relevant sources in the learning material on textbook products.

Some improvements that are the substance of learning materials, the use of sentences that are less precise, typos in writing, the use of false hyphens, and the design of social science for Primary school textbooks based on input and suggestions by experts, by following up the revisions to experts, so that the process of developing social science for Primary school textbook products can be deemed feasible by experts. The most emphasized aspect is the development of social studies education textbook products of social science for Primary school is the strength of the text that contains the concepts of social sciences, and is in accordance with the purpose of developing social science for Primary school textbook products with the 2013 curriculum-based concept approach.

\section{CONCLUSION}

Based on the description of the results of the research and discussion it can be concluded that the textbooks for Social Sciences of Madrasah Ibtidaiyah/primary school teacher education using the 2013 curriculum-based concept are categorized as feasible. For this reason, this textbooks can be a reference for lecturers who are teaching social science education courses in Madrasah Ibtidaiyah/primary school. So that it was expected that by using this textbooks, the learning outcomes of the social science education courses could be achieved optimally. Furthermore, the research and development of the social science for Primary school textbook will be continued using an expanding community approach that aims to determine the breadth of material based on the development of social science for Primary school textbooks using a conceptual approach.

\section{REFERENCES}

Amin, S. (2017). Pengembangan Bahan Ajar Geografi Terintegrasi Sains Islam di Madrasah. Jurnal Pendidikan: Teori, Penelitian, dan Pengembangan, 2(7), 934-945. https://doi.org/10.17977/jptpp.v2i7.9676.

Dewi, A. E. A., \& Mukminan, M. (2016). Implementasi Pendekatan Saintifik dalam Pembelajaran IPS di Middle Grade SD Tumbu 3 Kota. Jurnal Prima Edukasia, 4(1), 20 31. https://doi.org/10.21831/jpe.v4i1.7691.

Hanafiyah, H., \& Supardi, S. (2016). Penggunaan Media Puzzle Untuk Meningkatkan Hasil Belajar IPS Tentang Perkembangan Teknologi Produksi, Komunikasi, dan Trasnportasi. Ibtida 'i: Jurnal Kependidikan Dasar, 3(02), 139.

Jacobsen, D. A., Eggen, P. D., \& Kauchak, D. P. (2002). Methods for teaching: Promoting 
student learning. Merrill/Prentice Hall.

Krismawati, N. U., Warto, W., \& Suryani, N. (2018). Analisis Kebutuhan pada Bahan Ajar Penelitian dan Penulisan Sejarah di Sekolah Menengah Atas (SMA). Briliant: Jurnal Riset dan Konseptual, 3(3), 300-311. https://doi.org/10.28926/briliant.v3i3.202.

Lukman, L., \& Ishartiwi, I. (2014). Pengembangan bahan ajar dengan model mind map untuk pembelajaran ilmu pengetahuan sosial SMP. Jurnal Inovasi Teknologi Pendidikan, 1(2), 109-122.

Miftahuddin, M. (2016). Revitaslisasi IPS dalam Perspektif Global. Jurnal Pemikiran Keislaman, 27(2), 284-267. https://doi.org/10.33367/tribakti.v27i2.269.

Muna, I. A. (2016). Identifikasi Miskonsepsi Mahasiswa PGMI pada Konsep Hukum Newton Menggunakan Certainty of Response Index (CRI). Cendekia: Jurnal Kependidikan Dan Kemasyarakatan, 13(2), 309-322. https://doi.org/10.21154/cendekia.v13i2.251.

Mursalin. (2014). Meminimalkan Miskonsepsi pada Materi Rangkaian Listrik dengan Pembelajaran Predict-Observe-Explain. Jurnal Ilmu Pendidikan, 20(1). https://doi.org/10.17977/jip.v20i1.4383.

Muspiroh, N. (2015). Pembelajaran Tematik Integratif IPA dan IPS di Madrasah Ibtidaiyah pada Kurikulum 2013. Al Ibtida: Jurnal Pendidikan Guru MI, 2(2). https://doi.org/10.24235/al.ibtida.snj.v2i2.126.

Nurjannah, N. (2017). Pengembangan Pembelajaran IPS Berwawasan Kebangsaan Sebagai Matakuliah Jati Diri di Fakultas Ilmu Sosial UNIMED. JUPIIS: JURNAL PENDIDIKAN ILMU-ILMU SOSIAL, 9(2), 133-140. https://doi.org/10.24114/jupiis.v9i2.8241.

Prasetiyo, N. A., \& Perwiraningtyas, P. (2017). The Development of Environment based Textbook in Biology Course at Tribhuwana Tunggadewi University. Jurnal Pendidikan Biologi Indonesia, 3(1), 19. https://doi.org/10.22219/jpbi.v3i1.3969.

Puspitasari, R. (2016). Penanaman Nilai Karakter Peduli Lingkungan dalam Muatan Enviromental Education Pada Pembelajaran IPS dI MI Darul Hikam Kota Cirebon. Al Ibtida: Jurnal Pendidikan Guru MI, 3(1). https://doi.org/10.24235/al.ibtida.snj.v3i1.547.

Retariandalas, R. (2017). Pengaruh Minat Membaca dan Motivasi Belajar Terhadap Prestasi Belajar IPA Siswa. Formatif: Jurnal Ilmiah Pendidikan MIPA, 7 (2). https://doi.org/10.30998/formatif.v7i2.1529.

Riwanda, A., Fani, A., \& Islamy, M. I. (2017). A Correlation Between the Use of Internet as Learning Source, Learners'learning Autonumous and Learners'engagement in Learning Process (Vol. 2, pp. 299-307). Presented at the Proceeding International Conference on Islamic Education (ICIED).

Rohmah, D. F., Hariyono, H., \& Sudarmiatin, S. (2017). Pengembangan Buku Ajar IPS SD Berbasis Kontekstual. Jurnal Pendidikan: Teori, Penelitian, dan Pengembangan, 2(5), 719-723. https://doi.org/10.17977/jptpp.v2i5.9200.

Ross, E. W. (2014). Social Studies Curriculum, The: Purposes, Problems, and Possibilities. New York: SUNY Press.

Setiawan, D. (2013). Reorientasi Tujuan Utama Pendidikan Ilmu Pengetahuan Sosial Dalam Perspektif Global. JUPIIS (Jurnal Pendidikan Ilmu-Ilmu Sosial), 5(2). Retrieved from https://doaj.org.

Subadi, T., Priyono, K. D., Dahroni, D., \& Musyiyam, M. (2015). Implementasi Pembelajaran IPS Berbasis Kurikulum 2013 Melalui Lesson Study di Sekolah Muhammadiyah Kartasura. Warta LPM, 18(1), 62-75. https://doi.org/10.23917/warta.v18i1.1168. 
Surahman, E., \& Mukminan, M. (2017). Peran guru IPS sebagai pendidik dan pengajar dalam meningkatkan sikap sosial dan tanggung jawab sosial siswa SMP. Harmoni Sosial: Jurnal Pendidikan IPS, 4(1), 1. https://doi.org/10.21831/hsjpi.v4i1.8660.

Susanti, S. (2016). Metode mind mapping untuk meningkatkan hasil belajar IPS di Sekolah Dasar. 14. Jurnal Pendidikan Guru Sekolah Dasar, 1(1).

Susilaningsih, E., Kasmui, K., \& Harjito, H. (2016). Desain Instrumen Tes Diagnostik Pendeteksi Minkonsepsi untuk Analisis Pemahaman Konsep Kimia Mahasiswa Calon Guru. Unnes Science Education Journal, 5(3). https://doi.org/10.15294/usej.v5i3.13184.

Sutrisna, E., \& Wasino, W. (2010). Pembelajaran IPS dalam Realita di Era KTSP: Studi Eksplorasi Pelaksanaan Pembelajaran IPS pada Jenjang SMP di Kabupaten PATI. Paramita: $\quad$ Historical Studies https://doi.org/10.15294/paramita.v20i2.1049.

Suwarni, E. (2015). Pengembangan Buku Ajar Berbasis Lokal Materi Keanekaragaman LabaLaba di Kota Metro Sebagai Sumber Belajar Alternatif Biologi Untuk Siswa SMA Kelas $\begin{array}{llll}\text { X. BIOEDUKASI (Jurnal Pendidikan } & \text { Biologi), }\end{array}$ https://doi.org/10.24127/bioedukasi.v6i2.336.

Taba, H. (1967). Teachers' Handbook for Elementary Social Studies. Michigan: Addison Wesley.

Tanjung, A., \& Fahmi, M. (2015). Urgensi pengembangan bahan ajar geografi berbasis kearifan lokal. Jurnal Pendidikan Geografi: Kajian, Teori, dan Praktek dalam Bidang Pendidikan dan Ilmu Geografi, 20(1), 24-29.

Thiagarajan, S. (1974). Instructional Development for Training Teachers of Exceptional Children: A Sourcebook. Minnesota: The University of Minnesota.

Wijayati, E. C., Degeng, I. N. S., \& Sumarmi, S. (2016). Kesulitan-Kesulitan dalam Implementasi Kurikulum Mata Pelajaran IPS SMP. Jurnal Pendidikan: Teori, Penelitian, dan Pengembangan, 1(11), 2241-2247. https://doi.org/10.17977/jp.v1i11.8132. 